\title{
Analysis of the impact of the Work From Home Policy on Changes in Stock Prices and Transaction Volume Study of Telecommunications Companies at IDX
}

\author{
Arie Setyo Dwi Purnomo \\ Faculty Economic and Bussines, Univercity Trunojoyo Madura
}

Arie.dwip@Trunojoyo.ac.id

\section{Kata kunci:}

WorK From Home

Stock Price

Volume

Telecomunication

\section{Keywords:}

WorK From Home

Stock Price

Volume

Telecomunication

Arie Setyo Dwi Purnomo (2020). Analysis Of The Impact Of The work Home Policy On Changes In Stock Prices And Transaction Volume Study Of Telecommunications CompaniesAt IDX. Akuntabilitas: Jurnal Ilmiah Ilmu-Ilmu Ekonomi, 13(2), 30-38

\begin{abstract}
ABSTRAK
Kebijakan work from home akibat pandemic covid 19 merupakan salah satu alternative dalam mencegah penyebaran virus covid 19. Masyarakat secara umum harus membiasakan bekerja dan belajar dengan memanfaatkan jaringan telekomunikasi dalam menunjang pekerjaan. Kenaikan trafik jaringan internet diharapkan memberikan stimulus terhadap perusahaan telekomunikasi. Penelitian ini menguji mengenai sentiment wotk from home terhadap perubahan harga dan volume transaksi saham dua perusahaan yakni PT. Telkom Indonesia Tbk dan PT. XL Axiata. Tbk. Teknik analisis pada penelitian ini menggunakan teknik analisis kuantitatif dengan uji sample paired $t$-test. Data yang dikumpulkan dari Bursa Efek Indonesia dengan jenis data sekunder. Peneliti menggunakan uji sample paired t-test menggunakan software SPSS 21. Hasil penelitian diketahui PT Telkom Indonesia Tbk mengindikasikan terjadi perubahan harga yang signifikan sebesar Rp 343 sebelum kebijakan namun volume transaksi meningkat sesudah pengumuman kebijakan work from home. PT XL Axiata Tbk terjadi perubahan signifikan sebesar Rp 126 lebih tinggi sebelum kebijakan work from home namun volume transaksi tidak ada pengaruh signifikan sebelum dan sesudah kebijakan work from home.
\end{abstract}

\section{ABSTRACT}

The work from home policy due to the COVID 19 pandemic is an alternative in preventing the spread of the COVID 19 virus. The general public must get used to working and learning by utilizing telecommunications networks to support work. The increase in internet network traffic is expected to provide a stimulus for telecommunications companies. This study examines the sentiment of work from home to changes in price and transaction volume of shares of two companies, namely PT. Telkom Indonesia Tbk and PT. XL Axiata. Tbk. The analysis technique in this study uses quantitative analysis techniques with a paired t-test sample test. Data collected from the Indonesia Stock Exchange with the type of secondary data. Researchers used the paired t-test sample test using SPSS 21 software. The results showed that PT Telkom Indonesia Tbk indicated a significant price change of $R p .343$ before the policy but the volume of transactions increased after the announcement of the work from home policy. PT XL Axiata Tbk had a significant change of Rp. 126 which was higher before the work from home policy, but the transaction volume had no significant effect 


\section{INTRODUCTION}

Coronavirus Disease 2019 (Covid-19) has become a world epidemic. Until the first week of May 2020, there were at least 4.1 million people (276 thousand of them died) from 212 infected countries (Amanani, 2020). The outbreak has also caused more than 8.9 billion people in Asia, America, Europe, Australia, Africa, and Antarctica to feel worried. Some of them have to go through a social distancing phase (maintaining a safe distance, staying at home, working at home, even praying at home) for months. To prevent, or at least suppress, the rate of transmission of a number of the main affected countries have implemented lockdowns, regional quarantine, to large-scale social restrictions (PSBB)

Indonesia is one of the countries affected. The first announcement of the Covid-19 case was on March 2, which was announced directly by the president on March 2, 2020. After this announcement, the government on March 13, 2020, immediately formed a Task Force for the acceleration of handling Covid-19. This task force prepares all policies in coordination with the Ministry of Health (Kompas, $2020 b)$. This has resulted in various policies carried out by the government to prevent the spread of the Covid-19 outbreak, including by carrying out physical distancing, wearing masks, dismissing schools, doing work from home, and regulating daily health protocols (Junaedi \& Salistia, 2020)

Work from home is one of the policies recommended by the government. In the first week, positive cases of Covid-19 were found, namely the 15th in several government agencies and followed by companies (Kompas, 2020a). The general definition of work from home is a term working remotely using the media of information technology, more precisely working from home. So workers do not need coming to the office face to face with other workers. Work from home is familiar to freelancers, but they often call it remote working or remote working. Work from home and remote working is the same, the only difference is the regulations of the company or institution they works. Some apply normal working hours 8 am to $4 \mathrm{pm}$ or free work hours as long as work is done and communication can be a fast 
response. Crosbie and Moore, (2004) working from home means paid done primarily from home (minimum 20 hours per week). Working from home will provide flexible time for workers to provide a balance of life for employees. On the other hand, it also provides benefits for the company.

Work from home will not be maximized without the role of information technology that supports the success of work in this pandemic which minimizes direct contact as long as vaccines are not yet found.

The response of the capital market to this announcement was immediately greeted by negative sentiment with the fall in the JCI share price by $1.6 \%$ to the position of 5,361. All investors lose ownership of blue chips. The worst decline occurred on March 9, 2020, amounting to $6.5 \%$ to the level of 5,136. so that the Indonesia Stock Exchange issued a trading policy halt. Trading is suspended if the decline is $5 \%$ for 30 minutes and suspended if the JCI drops to $15 \%$. However, this decline continued on March 12, 2020 (Sugianto, 2020)

In other studies, several analyzed the announcement of the first Covid-19 in their country. Abu Bakar, (2020) regarding the impact of Covid-19 on the capital market with the results outbreak of the Covid-19 case in Malaysia made investors sell their equity which caused the KLSE composite stock price to decline. This is different from research Sansa, (2020) that changes in the Shanghai Stock Exchange and New York Dow Jones stock exchanges have a positive correlation with the number of Covid-19 cases.

This study will look at the correlation regarding the work from a home policy on changes in stock prices of telecommunications companies and the volume of stock price transactions amid the Covid-19 pandemic. This was done because the Covid-19 pandemic was a disease that could paralyze the world economy from a health risk aspect

The formulation of the problem in this study can be explained as follows:

1. What is there a significant difference in the share price of PT. Telkom Indonesia Tbk before and after the national announcement regarding the work from home policy? 
2. What is there a significant difference in the volume of share transactions of PT. Telkom Indonesia Tbk before and after the national announcement regarding the work from home policy?

3. What is there a significant difference in the share price of PT. XL Axiata Tbk before and after the national announcement regarding the work from home policy?

4. What Is there a significant difference in the share transaction volume of PT. XL Axiata Tbk before and after the national announcement regarding the work from home policy?

\section{RESEARCH METHOD}

This research includes quantitative research using secondary data, namely closing stock prices and transaction volume from PT. Telkom Indonesia Tbk. and PT. XL Axiata Tbk. The data taken is 30 days before and 30 days after the announcement of work from home appeal and online school policies. In this study using data obtained from the yahoo finance website and the Indonesia Stock Exchange. The share price used is the closing price. Closing price data uses daily data. Meanwhile, the amount of transaction volume per sheet is taken from the daily transaction volume of PT. Telekom Indonesia Tbk, and PT Excel Axiata Tbk. Testing in this study using paired sample t-test. It is used to measure how much change in stock prices and transaction volume occurred before the work from home and study at home policy was announced and after the policy announcement. The research data were processed using SPSS 21 software tools. The criteria for the data taken are described below::

1. Data prior to the announcement of Work From Home (WFH) policy in Indonesia for the first day (X1). Data for the first WFH policy announcement includes data on share prices and transaction volume of PT. Telkom Indonesia Tbk and PT Excel Axiata Tbk. The time span for data collection is 30 days before the Work From Home policy is enforced

2. Data after the national announcement of the Work From Home policy. This first announcement data includes data on share prices and 
transaction volume of PT. Telkom Indonesia and PT. Axiata Tbk. The data retrieval time takes 30 days after the Work From Home policy is enforced

3. The Work From Home Policy in Indonesia was first implemented on 20 March 2020. This is from the Letter of the President of the Republic of Indonesia and the Circular of the Minister of PAN-RB of the Republic of Indonesia Number 19 of 2020 concerning Adjustments to the Work System of State Civil Apparatus in Efforts to Prevent the Spread of Covid-19 within government agencies and participated by the private sector

The method used in this research is the t-test, namely the parametric onesample t-test. Assuming the data is normally distributed.

\section{DISCUSSION}

Changes Share Prices and Transaction Volume at PT Telkom Indonesia on the IDX before and after the announcement of the work from home policy

Table 1

Descriptive Statistics

\begin{tabular}{|c|c|c|c|c|c|}
\hline & $\mathrm{N}$ & Minimum & Maximum & Mean & $\begin{array}{c}\text { Std. } \\
\text { Deviation }\end{array}$ \\
\hline X1Telkom & 30 & 2620,00 & 3830,00 & 3435,2381 & 317,05865 \\
\hline X2Telkom & 30 & 2620,00 & 3330,00 & 3091,4286 & 169,47819 \\
\hline Vol1TLKM & 30 & 53035400,00 & 151751800,00 & 107410247,14 & $\begin{array}{r}28836326,500 \\
1 \\
\end{array}$ \\
\hline $\begin{array}{l}\text { VolX2TLK } \\
\text { M }\end{array}$ & 30 & 45469500,00 & 357680089,00 & 139488106,14 & $\begin{array}{r}75119923,592 \\
7\end{array}$ \\
\hline $\begin{array}{l}\text { Valid N } \\
\text { (listwise) }\end{array}$ & 30 & & & & \\
\hline
\end{tabular}

Source: SPSS 21

In the results of the statistical description table 1 of the change in share price (X1) before the implementation of the work from home policy in Indonesia for the first time on March 20, 2020. share price PT Telkom Indonesia before the announcement of this policy averaged IDR 3435 (X1) and the price shares after the announcement of work from home averaged Rp. 3091 (X2). In the aspect of 
transaction volume before applied policy, namely in the Vol1 variable, the average transaction volume reached 107,410,247 shares daily and after the work from home policy became $139,488,106$ shares. The data in this study were taken from 30 days before and after the announcement of the work from home policy.

In table 2 using paired sample t-test data using the SPSS 21 application. From the results of the analysis, the significance value is 0.00 which is smaller than the 0.05 significance. These results indicate that there is a significant difference in changes in the share price of PT Telkom Indonesia before and after the work from home policy is implemented in Indonesia. The value of change in stock prices is also positive, which has an interpretation that the price has a difference of Rp. 343. This indicates that the initial average value before the WFH policy has a higher price than after the announcement of work from home.

Table 2

\section{Paired Samples Test}

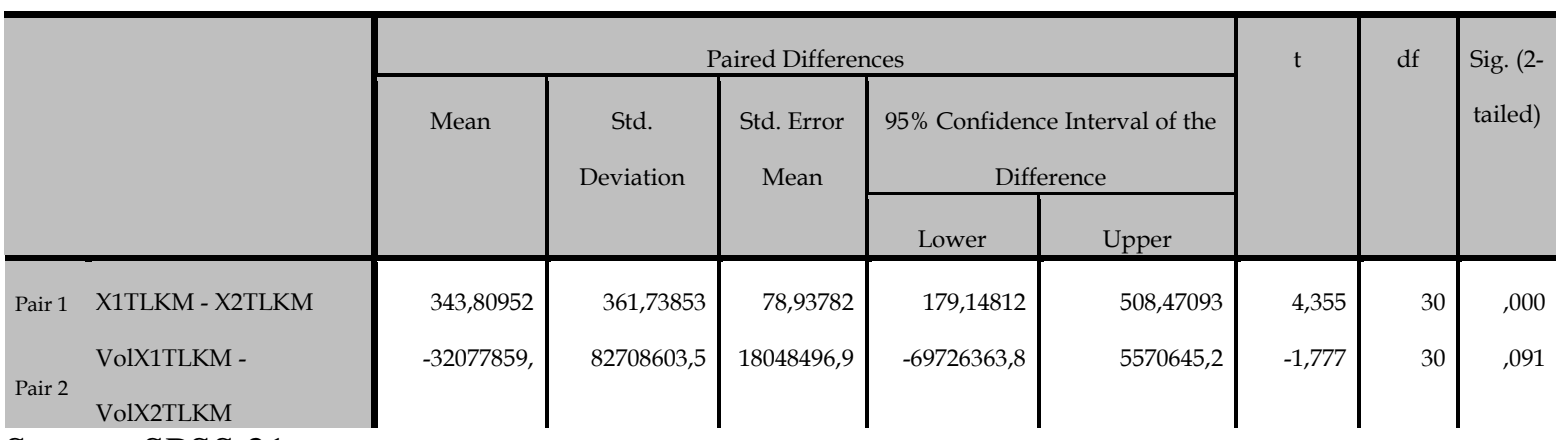

Source: SPSS 21

While in the aspect of change in transaction volume, it has a significant value of 0.091 which is smaller than the significant of 0.05 . This result is significant at the $10 \%$ level. Meanwhile, the value of -32077859 This value is negative. The interpretation before the announcement of the work from home policy in Indonesia has an average value smaller than the average value of transaction volume after the announcement. This value indicates an increase in the average volume of stock transactions at PT Telkom Indonesia Tbk. This increase could be caused by the sentiment of stock market players (CNBC, 2020) 
The Changes in share prices and transaction volume at PT XL Axiata Tbk on the IDX before and after the announcement of WFH policies

Table 3 PT XL Axiata Tbk

Description Statistic

\begin{tabular}{l|r|r|r|r|r} 
& N & \multicolumn{1}{|c|}{ Minimum } & \multicolumn{1}{c}{ Maximum } & \multicolumn{1}{c}{ Mean } & \multicolumn{1}{c}{ Std. Deviation } \\
\hline X1Excel & 30 & 1410,00 & 2680,00 & 2208,8095 & 415,81818 \\
\hline X2Excel & 30 & 1410,00 & 2400,00 & 2082,1429 & 288,73245 \\
\hline VolX1Excel & 30 & 4997000 & 97457400 & 20395167,4 & 18704475 \\
\hline VolX2Excel & 30 & 6483900 & 4982500 & 19261386,9 & 10004953 \\
\hline Valid N (listwise) & 30 & & & &
\end{tabular}

Source: SPSS 21

Furthermore, the results of the statistical description table 3 of changes in stock prices (X1 Excel) before the implementation of the WFH policy in Indonesia for the first time on March 20, 2020. The share price of PT XL Axiata Tbk before the announcement of the work from home policy averaged Rp. 2208 (X1 Excel) and the average stock price after work from home announcement was Rp. 2082 (X2 Excel). In the aspect of the transaction volume before the announcement of the policy work from home that is on the $\mathrm{X} 2$ with the average transaction volume shares reached 20,395,167 after the daily and work from home policies in effect be 19,261,386 shares. The data in this study were drawn from the 30 days before and after the announcement of the policy work from home.

In Table 4 using a paired sample test data processing using SPSS 21. From the analysis of the significance of 0,026 is worth less than the 0.05 significance. These results indicate that there is a significant difference in changes in the share price of PT XL Axiata Tbk before and after the work from home policy is implemented in Indonesia. Value changes in stock prices are also a positive value which has the interpretation that the price has a difference of $\operatorname{Rp} 126$ higher. This shows that the initial average value before the work from home policy has a higher price than after the work from the home announcement. This policy has not been able to provide a positive sentiment on the performance of PT. XL Axiata Tbk. This is influenced by the company's performance that is less than PT. Telkom Indonesia Tbk. This is 
Table 4

Paired Sample Test

\begin{tabular}{|c|c|c|c|c|c|c|c|c|c|}
\hline & & \multicolumn{5}{|c|}{ Paired Differences } & \multirow[t]{3}{*}{$\mathrm{t}$} & \multirow[t]{3}{*}{$\mathrm{df}$} & \multirow{3}{*}{$\begin{array}{l}\text { Sig. (2- } \\
\text { tailed) }\end{array}$} \\
\hline & & \multirow[t]{2}{*}{ Mean } & \multirow[t]{2}{*}{$\begin{array}{c}\text { Std. } \\
\text { Deviation }\end{array}$} & \multirow[t]{2}{*}{$\begin{array}{c}\text { Std. Error } \\
\text { Mean }\end{array}$} & \multicolumn{2}{|c|}{$\begin{array}{c}95 \% \text { Confidence Interval of } \\
\text { the Difference }\end{array}$} & & & \\
\hline & & & & & Lower & Upper & & & \\
\hline Pair 1 & $\begin{array}{l}\text { X1Excel - } \\
\text { X2Excel } \\
\end{array}$ & 126,66667 & 648,71861 & 141,56201 & $-168,62650$ & 421,95984 & ,895 & 20 & ,026 \\
\hline Pair 2 & $\begin{array}{l}\text { VolX1Excel - } \\
\text { VolX2Excel }\end{array}$ & 1133780 & 22675459 & 4948190 & -9187964 & 11455526,1 & ,229 & 20 &, 000 \\
\hline
\end{tabular}

Source: SPSS 21

While the transaction volume change aspects have a significant value of 0.000 is smaller than the significance of 0:05. These results indicate that there is no significant difference in the total transaction volume of PT XL Axiata Tbk shares after and before the announcement of the work from home policy. The value of 1133780 has an interpretation that the average value of the share price transaction volume before the announcement of the work from home policy is higher than after the policy was implemented. So it can be said that the sentiment of market players towards this company has not been able to increase market volume.

\section{SUMMARY}

The conclusion obtained from the paired-sample t-test in this study, the stock price of PT Telkom Indonesia Tbk and PT XL Axiata Tbk. Before and after the announcement of the work from home policy, it shows a significant difference. This is indicated at the level of significance value below $5 \%$ or 0.05 .

Likewise, the transaction volume for PT XL Axiata Tbk shows a significant difference between before and after the announcement of work from home. Meanwhile, PT Telkom Indonesia found no significant changes at the level of significance below $5 \%$ or 0.05 . 
This study has limitations regarding the work from home policy sentiment towards telecommunication companies. Stock price and volume sentiment is not only influenced by one factor, so it is hoped that further research can examine the impact of internet quota subsidies on society, particularly in supporting work from home and home studies on stock price movements of telecommunications companies..

\section{REFERENCES}

Abu Bakar, N. (2020). Impact of Coronavirus Disease 2019 (COVID-19) to Equity Market and Currency Exchange Rate. IOSR Journal of Economics and Finance, 11(2), 22-31. https:/ / doi.org/10.9790/5933-1102062231

Amanani, N. (2020). Update 11 Mei_4,1 Juta Orang di Dunia Positif Corona COVID-19 Global Liputan6.

CNBC. (2020). Work From Home E PSBB, Saham Emiten Telko Ketiban "Berkah."

Crosbie, T., \& Moore, J. (2004). Work-life Balance and Working from Home. Social Policy and Society, 3(3), 223-233. https:// doi.org/10.1017/s1474746404001733

Junaedi, D., \& Salistia, F. (2020). Dampak pandemik Covid-19 terhadap pasar modal di Indonesia: studi kasus Indeks Saham Komposit (Ihsg). Al-Kharaj: Jurnal Ekonomi, Keuangan E Bisnis Islam, 2(4), 1-30.

Kompas. (2020a). Empat Kali Diperpanjang, WFH bagi ASN Terbaru Berlaku hingga 4 Juni Halaman all - Kompas.

Kompas. (2020b). Pengumuman Mendadak Jokowi yang Kejutkan Pasien Positif Corona.

Sansa, N. A. (2020). The Impact of the COVID-19 on the Financial Markets: Evidence from China and USA. SSRN Electronic Journal, April. https:/ / doi.org/10.2139/ssrn.3567901

Sugianto, D. (2020). Perjalanan IHSG Sejak RI Positif Virus Corona. In Finance.Detik.Com. https:/ finance.detik.com/bursa-dan-valas/d4972595/ perjalanan-ihsg-sejak-ri-positif-virus-corona 